УДК 005.22: 005.8: 681.3

(C) 2016

Ковнір Д. А., аспірант

(науковий керівник - кандидат економічних наук I. О. Кондратюк)

Київський національний економічний університет ім. Вадима Гетьмана

\title{
МЕХАНІЗМ ПРИЙНЯТТЯ УПРАВЛІНСЬКИХ РІШЕНЬ ДЕРЖАВНИМ ВИЩИМ НАВЧАЛЬНИМ ЗАКЛАДОМ НА ОСНОВІ РЕЗУЛЬТАТІВ АНАЛІЗУ
}

\section{Рецензент - доктор економічних наук В. В. Писаренко}

У статті запропоновано власне авторське визначення поняття «управлінські рішення», створено модель прийняття рішень на основі аналізу рівнів показників ефективності фінансового механізму державних вищих навчальних закладів та розроблено комплексну систему модельно-типового прийняття управлінських рімень державним вищим навчальним закладом на основі результатів аналізу. Надано рекомендаиії для прийняття управлінських рішень, відповідно до результатів проведеного аналізу господарської діяльності.

Ключові слова: механізм, управлінське рімення, державний вищий навчальний заклад (ДВНЗ), результати аналізу, модель, моделювання.

Постановка проблеми. Жодна установа, підприємство чи організація не зможуть ефективно функціонувати без належної системи управлінських рішень, в основі якої лежать проблематичні питання становища установи (підприємства), його можливих змін і подальшого розвитку. Під час прийняття управлінських рішень найбільш важливим $є$ результати аналізу господарської діяльності установи.

Причиною аналізу інформації, відображеної у фінансовій звітності є доступність форм звітності внутрішнім і зовнішнім користувачам, високий ступінь агрегованості даних, що охоплює всі сторони діяльності суб'єкта господарювання, можливість проведення багатопланового аналізу фінансового стану. Саме тому набуває актуальності проблема розробки механізму прийняття рішень на основі результатів аналізу $[8,10]$.

Аналіз останніх досліджень i публікацій, у яких започатковано розв'язання проблеми. Проблему прийняття управлінських рішень установами досліджували і описували в своїх працях багато провідних вчених, таких як: Ю. Ю. Бенедик [1], Т. М. Боголіб [2], І. М. Грищенко [4], В. П. Мартинюк [7], В. О. Матюхін [8], І. С. Стеців [11].

Однак, зважаючи на величезну кількість досліджень на дану тематику, потребує детального дослідження сам механізм прийняття управлінських рішень державним вищим навчальним закладом на основі результатів аналізу.

Мета дослідження - розробка цілісного, обгрунтованого механізму щодо прийняття управлінських рішень державним вищим навчальним закладом на основі результатів аналізу.

Завдання дослідження:

- дослідити сутність поняття «управлінське рішення»;

- дослідити механізм прийняття управлінських рішень;

- проаналізувати систему прийняття управлінських рішень ДВНЗ на основі результатів аналізу.

Результати дослідження. Управлінське рішення - це сукупність дій управлінцем 3 метою вирішення проблемних питань в установі.

Загалом термін «рішення» розуміють та трактують по-різному. Через свою багатогранність під ним бачать як результат вибору, так і акт. Що ж стосується конкретно управлінських рішень державних вищих навчальних закладів, до них висувається низка вимог, а саме:

- своєчасність - прийняття рішення повинно відбуватися у конкретний час (не раніше та не пізніше визначеного);

- повнота - рішення повинно повністю розкривати свій зміст, охоплювати весь керований предмет;

- повноваження - чітке виконання і дотримання управлінцем своїх прав та обов'язків;

- правомірність та законність - управлінське рішення повинно не суперечити нормам чинного законодавства;

- реальність - здатність до реалізації рішення;

- ефективність - забезпечення позитивних результатів реалізації рішення;

- чіткість - рішення повинно бути стислим, лаконічним та зрозумілим;

- наукова обгрунтованість - управлінське рішення повинно бути підтверджене необхідною інформацією та обгрунтоване.

Проблема механізму прийняття управлінських рішень на основі результатів аналізу досліджу- 


\section{СТОРІНКА МОЛОДОГО ВЧЕНОГО}

валась в контексті державних вищих навчальних закладів, оскільки сучасний ВНЗ - це складна динамічна система. Складність системи визначається різноманіттям видів діяльності: підготовка фахівців різного рівня, виконання наукових досліджень, допоміжні напрями роботи. Водночас всі напрями діяльності взаємозалежні як на рівні виробничих процесів, так і на організаційному рівні.

У силу різноманіття своєї діяльності державний ВНЗ має складну виробничу структуру. Основними ланками цієї структури є: ректорат, факультети, кафедри і допоміжні підрозділи. Ефективність управління такою складною структурою і матеріальними витратами є головною умовою проведення якісного науково-педагогічного процесу [8].

Модель прийняття рішень на основі аналізу рівнів показників ефективності фінансового механізму державних вищих навчальних закладів наведена на рисунку 1.

Варто зауважити, що прийняття управлінських рішень вимагає високого рівня професіоналізму та обізнаності суб'єкта управління. На жаль, на сьогодні близько 5-10 \% осіб, які приймають управлінські рішення компетентні у свойй діяльності. Крім цього, в процесі дослідження виявлено низку факторів, які впливають на ефективність прийняття управлінських рішень державним вищим навчальним закладом. До таких факторів можемо віднести: застосування до системи управління проектами наукових підходів i принципів, методів моделювання, методів теорії автоматизованого управління, методів мотивації якісного рішення тощо. Зазвичай в прийнятті будь-якого рішення наявні три основні моменти: інтуїція, судження і раціональність [5].
Зауважимо, що потреба в прийнятті управлінського рішення зумовлена або зовнішніми обставинами (припис вищої організації, регулювання відносин $з$ підприємствами та організаціями), або внутрішніми (стратегічні цілі організації, відхилення від заданих параметрів виробництва, виникнення вузьких місць, виявлення резервів, порушення трудової дисципліни, заохочення працівників тощо). В процесі дослідження розроблено власну комплексну систему модельнотипового прийняття управлінських рішень ВН3 (рис. 2).

Прийняття управлінських рішень за результатами проведеного аналізу здійснюється у рамках класичної моделі.

Прийняття управлінських рішень державними вищими навчальними закладами відбувається поетапно, тобто існує чітка послідовність. Так, на першому етапі відбувається економічний аналіз ситуації, постановка проблемних питань, дослідження основних факторів, які їх спричинили, збір та обробка необхідної інформації. На другому етапі - формування та детальний аналіз рішень, визначення та обрання найбільш ефективного серед них та його реалізація.

Механізм прийняття управлінських рішень державним вищим навчальним закладом на основі результатів аналізу наведений на рисунку 3.

Важливим елементом процесу прийняття управлінських рішень є оцінювання дій на різних його етапах. Так, на етапі діагностики проблеми - це оцінювання меж, масштабів та рівня поширення проблеми; на етапі обгрунтування оцінювання різних варіантів, запропонованих для вирішення проблеми; на етапі прийняття рішення - оцінювання очікуваних наслідків від його реалізації.

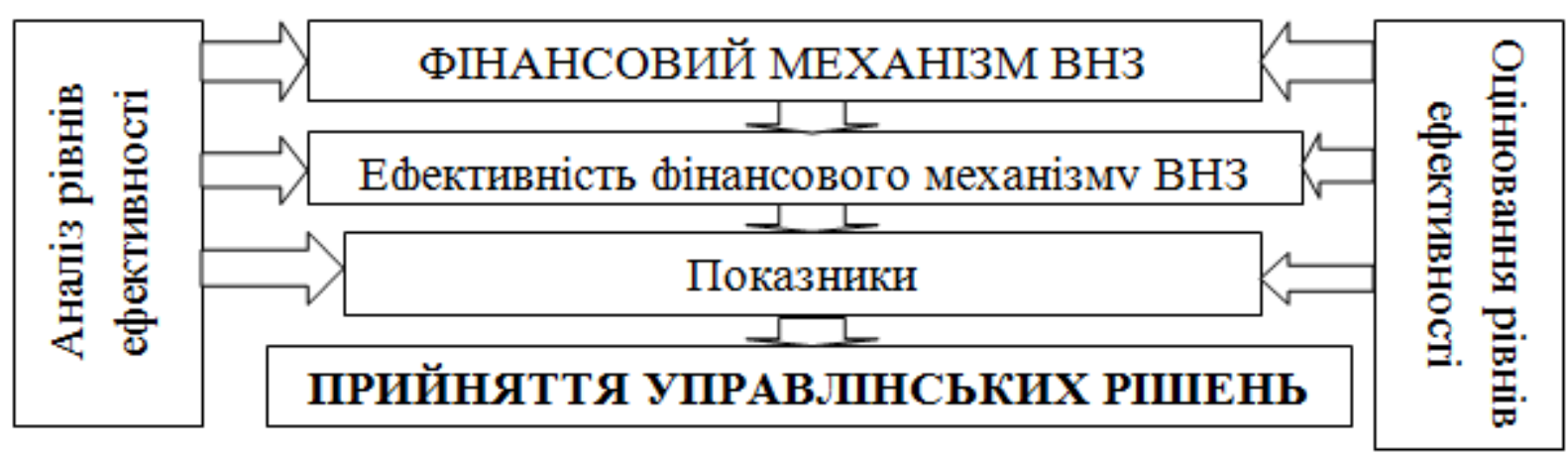

Рис. 1. Модель прийняття рішень на основі аналізу рівнів показників ефективності фінансового механізму державних вищих навчальних закладів

Джерело: сформовано автором за даними [10]. 


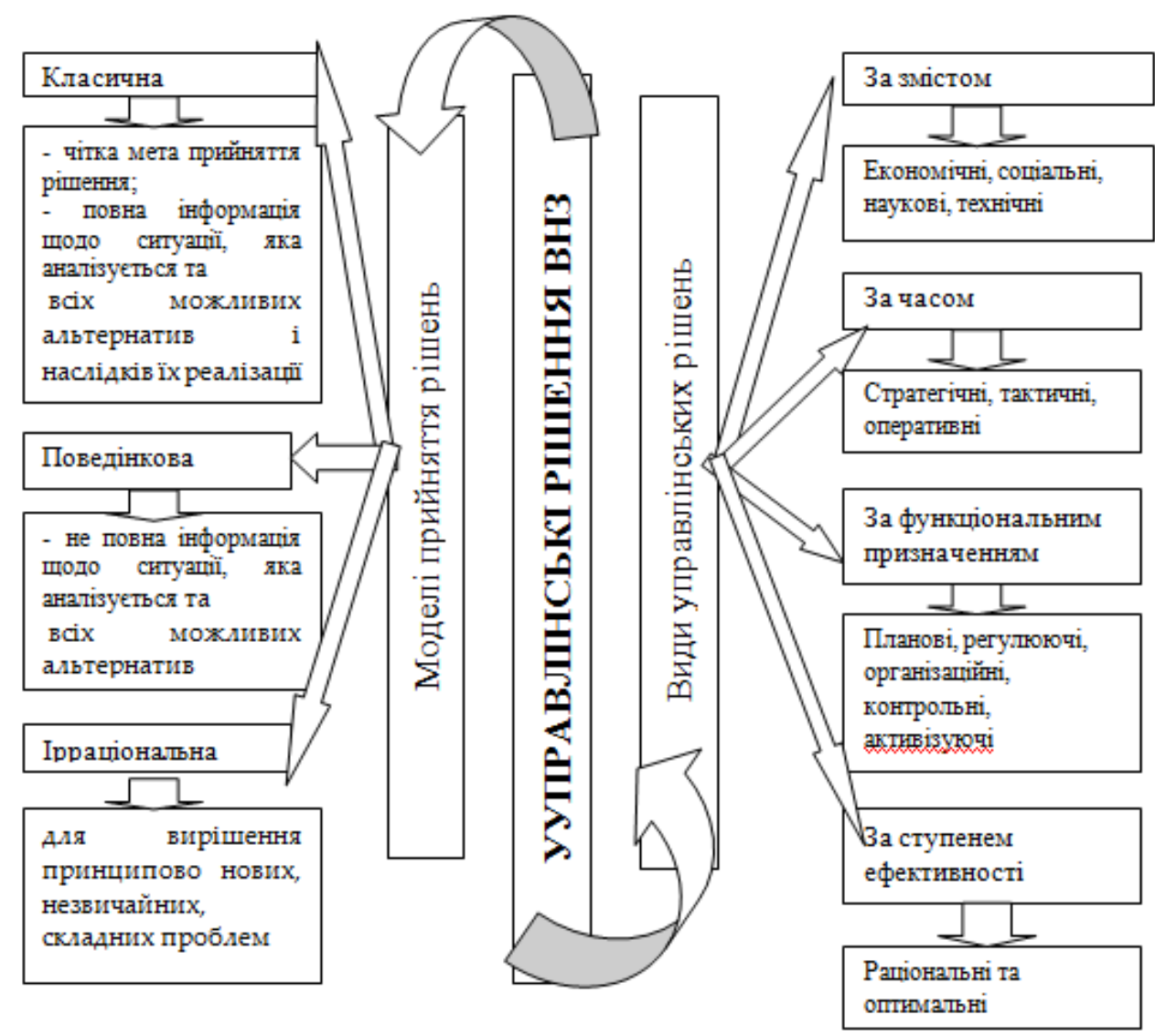

Рис. 2. Комплексна система модельно-типового прийняття управлінських рішень ВНЗ

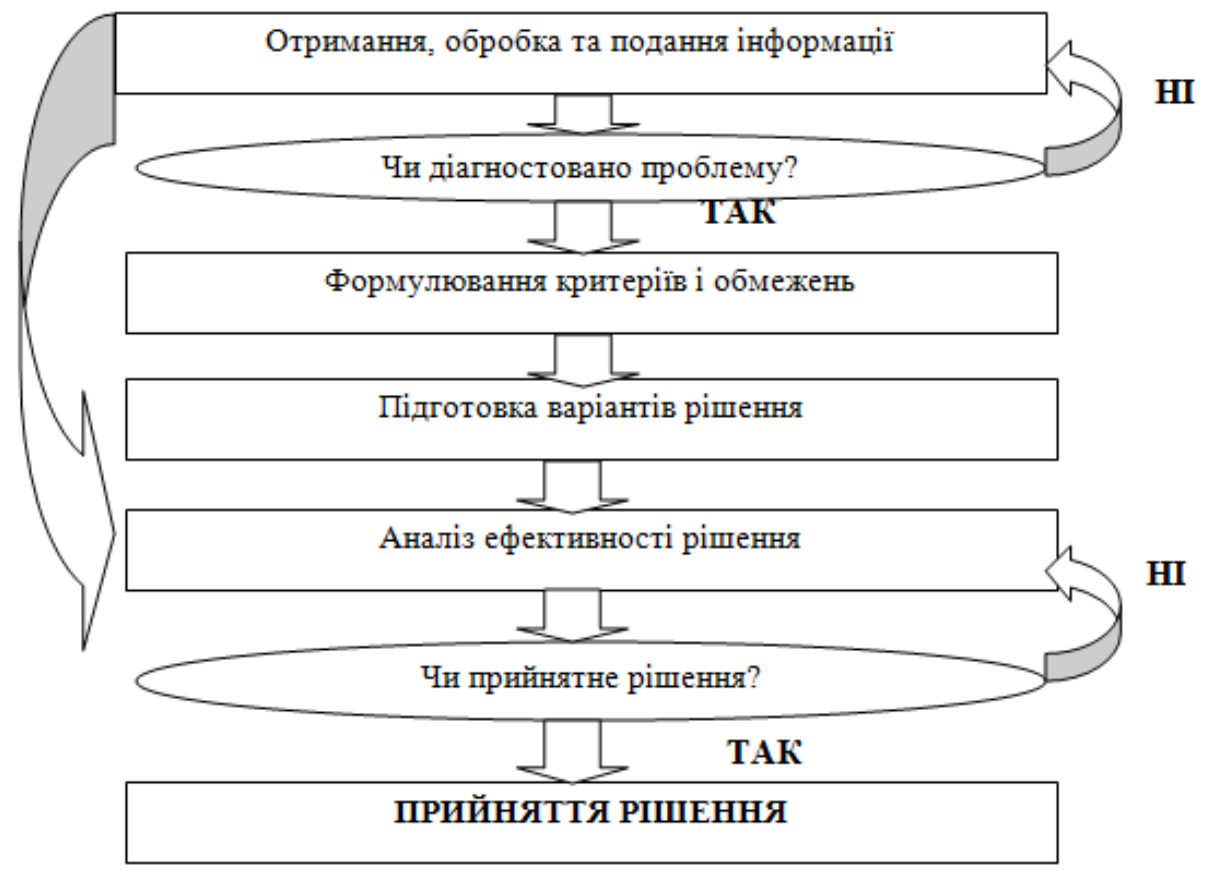

Рис. 3. Механізм прийняття управлінських рішень державним вищим навчальним закладом на основі результатів аналізу

Джерело: сформовано автором за даними [12]. 


\section{СТОРІНКА МОЛОДОГО ВЧЕНОГО}

Це оцінювання здійснюється за певними критеріями. На етапі підготовки критеріями розпізнавання проблеми найчастіше служить визначена ціль, відхилення від якої свідчить про наявність проблеми. Отже, керівники всіх рівнів мусять мати чітко сформульовані цілі та завдання своєї діяльності. За їх відсутності появу проблеми відчувають суто інтуїтивно або ж за надходженням сигналів, що суттєво ускладнює процес прийняття рішень. На етапі розроблення варіантів розв'язання проблеми застосовують різні критерії, які дають змогу обрати ті, що є найбільш доцільними. Від обгрунтованості цих критеріїв залежить якість управлінського рішення i, в кінцевому підсумку, адаптивність та ефективність організації [6].

Процес прийняття управлінських рішень на основі результатів аналізу набуває структурованого вигляду, адже в основі буде покладена побудова моделі. Використання моделювання спрямовано на детальне вивчення, максимальне удосконалення й одержання оптимального результату шляхом побудови моделей. Призначення аналітичних моделей полягає в оптимізації форми економічної інформації та методів дослідження. Використання моделей дає можливість акцентувати увагу на основних тенденціях, процесах і явищах.

Основною ціллю моделювання є створення умов для своєчасного та ефективного прийняття управлінських рішень, оптимізація процесу управління ВНЗ. Побудова моделей здійснюється на основі результатів попередньо проведеного аналізу вищого навчального закладу. Тому результат аналізу впливає на суть тих чи інших управлінських рішень. Якщо за результатами проведеного аналізу фінансовий стан ВНЗ є задовільним, установа розвивається та $є$ конкурентоспроможною на ринку, тоді управлінські рішення прийматимуться 3 метою підтримки існуючого стану ВНЗ. У протилежному випадку, тобто, коли результати аналізу вказують на проблематичний стан вищого навчального закладу,

\section{БІБЛІОГРАФІЯ}

1. Бенедик Ю. Ю. Взаємозв'язок між фінансовою стійкістю державного вищого навчального закладу та якістю освітніх послуг, які він надає / Ю. Ю. Бенедик // Науково-методичний журнал «Нова педагогічна думка». - Рівне, 2009. Спецвипуск №1. - С. 71-78.

2. Боголіб Т. М. Принципи управління вузом/ Т. М. Боголіб. - К. : Знання, 2004. - 204 с.

3. Гурч Л. М. Логістична та маркетингова орієнтація ринку освіти в Україні в контексті Бо- управлінські рішення будуть спрямовані на покращання діяльності установи.

Із проведеного дослідження можемо із впевненістю стверджувати про існування тісного зв'язку між результатами аналізу та управлінськими рішеннями, який приймається державним вищим навчальним закладом. До уваги беруться такі складові:

1. Фінансова складова - вважається провідною й вирішальною, оскільки у ринкових умовах господарювання фінанси є основою будь-якої економічної системи.

2. Інтелектуальна й кадрова складові, що охоплюють роботу 3 професорсько-викладацьким складом.

3. Технічна складова, що описує матеріальнотехнічне забезпечення навчального процесу.

Заслуговують на увагу технологічна та інформаційна складові. Перша несе у собі інформацію про дотримання вимог навчальних планів, друга ж - поєднання інформації зовнішнього (формується поза межами ДВНЗ) та внутрішнього середовищ (формується безпосередньо у процесі господарської діяльності ДВНЗ) [11].

Отже, із вищесказаного можемо зробити висновок, що прийняття управлінських рішень державним вищим навчальним закладом на основі результатів аналізу дає можливість: вносити своєчасні та ефективні зміни в процес управління ВН3, наукове обгрунтування управлінських рішень, ймовірність прийняття управлінських рішень.

Висновок. У даній статті науково обгрунтована сутність поняття «управлінське рішення» та досліджено механізм прийняття управлінських рішень державними вищими навчальними закладами на основі економічної інформації. У підсумку можемо сказати, що існує тісний взаємозв'язок результатів аналізу та управлінських рішень, адже тільки на основі результатів аналізу можна прийняти обгрунтовані управлінські рішення для ефективного функціонування державного вищого навчального закладу.

лонського процесу / Л. М. Гурч // Концептуальні засади формування менеджменту в Україні : збірник матеріалів Всеукраїнської науковопрактичної конференції. - К. : МАУП, 2006. C. 280-297.

4. Грищенко I. M. Економічна діяльність вищих навчальних закладів / I. М. Грищенко [Електронний ресурс]. - Режим доступу : http://er.knutd. com.ua/bitstream/123456789/790/1/V90sp_P021-028. pdf. 
5. Колпаков B. M. Теория и практика принятия управленческих решений : учеб. пособие / В. Н. Колпаков. - К. : МАУП, 2004. - 504 с.

6. Мармаза O. I. Інноваційні підходи до управління навчальним закладом [текст] : навч.метод. посібник / О. І. Мармаза. - Х. : Основа, 2004. - $240 \mathrm{c}$.

7. Мартинюк В. П. Економічна безпека вищих навчальних закладів в Україні: передумови оцінювання. Економіка Менеджмент Підприємництво, № 25(II). - 2013 / В. П. Мартинюк [Електронний ресурс]. - Режим доступу : http://eme.ucoz. ua/pdf/252/24.pdf.

8. Матюхін В.О. Організаційна модель та особливості менеджменту вищого навчального закладу / В. О. Матюхін, О. В. Кобзєва // Наукові праці МАУП. - К. : МАУП, 2006. - Вип. 1(13). C. 32-36.

9. Матюхін В. О. Організація практичної під- готовки і використання інформаційних технологій при очно-дистанційному навчанні / В. О. Матюхін, О. В. Кобзєва : матеріали V Міжнародної наукової конференції «Реалізація положень Болонської декларації в системі вищої освіти і науки України», м. Судак. - К. : МАУП, 2005. C. $247-253$.

10. Моісеєнко О. П. Оцінка показників діяльності вищого навчального закладу в процесах прийняття управлінських рішень / О. П. Моісеєнко // Праці Одеського політехнічного університету. - 2011. - №3. - С. 255-258.

11. Стеців I. C. Економічна безпека ВНЗ: сутність та особливості планування / I. С. Стеців [Електронний ресурс]. - Режим доступу : http://vlp.com.ua/node/6624.

12. Федулова Л. І. Актуальні проблеми менеджменту в Україні / Л. І. Федулова. - К. : Фенікс, 2005. $-320 \mathrm{c}$. 